\title{
Fiery Metaphors in the Public Space: Celebratory Culture and Political Consciousness around the Peace of Utrecht
}

\author{
Willem Frijhoff
}

In the evening of 13 April 2013, the Tercentenary celebration of the Peace Treaty of Utrecht was inaugurated by a sensational event that took place on top of the A2 motorway and was finished by spectacular fireworks. ${ }^{1}$ Three centuries earlier, fireworks also marked the end of the war and the conclusion of the Utrecht Peace in the principal cities of the former belligerent nations. Why fireworks? Why the visual representation of fire as the zenith of such a political celebration? There are some good reasons for this practice. While massive public rejoicings usually feature open-air festivities visible on a large scale, the popular success of fireworks is rooted above all in the social and cultural anthropology of the element 'fire'. The use and experience of fire and its (changing) meanings in ancient and non-Western societies as well as in Western civilization have been at the core of a long series of seminal works from various disciplines in the humanities and social sciences, not to speak of occultism and esotericism. ${ }^{2}$

For these authors, fire is the ultimate proof of resistance, truth and veracity. Moreover, as a spectacular, moving form of lightning, fire is also a symbol of

1 The spectacle can be viewed at ' 3 voor 12,' VPRo, http://3voor12.vpro.nl/lokaal/utrecht/ nieuws/2013/april/3voor12-Utrecht-TV--De-Slag-om-Vrede.html, accessed 1 November 2013.

2 Among the most important are James George Frazer, Myths on the Origin of Fire (London: Macmillan, 1930); Gaston Bachelard, The Psychoanalysis of Fire [1938], trans. Alan M.C. Ross (Boston: Beacon Press, 1964); Claude Lévi-Strauss, Mythologiques: The Raw and the Cooked [1964] (London: Cape, 1970); Jacques Le Goff, The Birth of Purgatory [1981] (London: Scolar Press, 1984); Géza Róheim, Fire in the Dragon, and other Psychoanalytic essays on Folklore, ed. Alan Dundes (Princeton, N.J.: Princeton University Press, 1992); Johan Goudsblom, Fire and Civilization (London: Allan Lane, 1992); Jonathan Sternfield, Firewalk: The Psychology of Physical Immunity (Stockbridge: Berkshire House, 1992); Richard W. Wrangham, Catching Fire: How Cooking Made Us Human (New York: Basic Books, 2009); Frances D. Burton, Fire: The Spark that Ignited Human Evolution (Albuquerque: The University of New Mexico Press, 2009); Nevill Drury, Stealing Fire from Heaven. The Rise of Modern Western Magic (New York: Oxford University Press, 2011).

(C) KONINKLIJKE BRILL NV, LEIDEN, 2015 | DOI 10.1163/9789004304789_015 
energy, passion and love, of the desire for purity and the aspiration to gain access to higher, intangible values. Finally, as an airy element fire is a metaphor for transition and transformation. Fire graphically represents the sparkling victory of the world of light over the universe of darkness. Fire elucidates the dangers and destroys the past, leaving behind a fertile soil where soon new shoots emerge to shape a fresh, new world. Therefore fire embodies hope, and an entirely new beginning. It brings the spectators together in a sense of redemption and of community without divisions or borders. The fascination with fire, either as a danger or as a source of hope, has therefore firm anthropological roots that explain why mass festivities generally include some form of performance in which fire plays a determinant role.

The best known and most universally appreciated of those performances involve fireworks. ${ }^{3}$ Independently of the idiosyncrasies of various human civilizations, fireworks are considered everywhere the ultimate celebratory performance, in the East as well as in the West. Fireworks technology, pyrotechnics, came to the West from the East, from China in particular. It probably spread from Italy (Vicenza 1379) and the Holy Roman Empire (Vienna 1438, Constance 1506, Nuremberg 1536) to France and the Netherlands. At first it served military aims and it has long continued to do so, but in the second half of the sixteenth century the first recreational fireworks emerge in our sources, in particular in our visual evidence. As early as the last quarter of the sixteenth century images of fireworks were published, and soon no public fireworks were performed without a pictorial publication of their exhibition.

Yet fire had been playing its role in public celebrations or recreational activities for centuries before this time, mainly in the form of bonfires (the pektonnen of the Dutch), an older, fixed variety of fiery performance that could be lighted without an explosive ignition. ${ }^{4}$ But once adopted in Western Europe during the sixteenth century, recreational or celebratory fireworks have taken root and developed their own modalities characteristic either of the hierarchical or of the more popular organization of the societies of Europe. Fireworks could serve to sing the praises of the highest authority of the state and their victories, as well as celebrate the unity and cohesion of the community. Over the past centuries there has virtually been no major event or festivity in Western Europe that was not finished, solemnly concluded, and anchored

3 Kevin Salatino, Incendiary art: the representation of fireworks in early modern Europe (Los Angeles: Getty Research Institute, 1997); D.P. Snoep, Praal en propaganda. Triumfalia in de Noordelijke Nederlanden in de $16^{e}$ en $17^{e}$ eeuw (Alphen aan de Rijn: Canaletto, 1975).

4 A useful survey of fireworks technology and its evolution, including references to ancient treatises and literature, in the article 'Feuerwerk', http://linux2.fbi.fh-koeln.de/rdk-smw/ Feuerwerk, accessed 1 November 2013. 
in the community's memory by the performance of fireworks. Moreover, the steady repetition of fireworks in the public space has moulded them into the universal political manifestation par excellence. As visible manifestations in the undivided sky, fireworks transcend political divisions, even if the political message attached to them by the organizers or the political authorities may be skilfully directive. They celebrate events that are meaningful for the whole community: the conclusion of a peace treaty, the birth or the advent of a new ruler or the confirmation of his or her reign, a military victory, the reception of a powerful friend, or the anniversary or the remembrance of an historical event. Though the anthropological values of fire are virtually never made explicit, they play their role in the background for motivating the complicated set-up of fireworks, justifying the often considerable expense, and shaping the constructions from which the fireworks will be set off and which will have to confer a precise meaning on the fireworks in the eyes of the spectators.

In addition to the meanings that are plain and publicly known, others are hidden behind the visual performance or embodied in the shape of the fireworks. Quite often a more intricate or complicated web of surreptitious or overt meanings is involved, which has been set up by the founding authorities and the designers and architects who created the fireworks on their behalf. Such hidden meanings need an elaborate explanation in order to be rightly understood. Fireworks are therefore an intricate and rich instrument of cultural communication that can be used at several levels, and it is as means of communication that we should analyse them. They embrace different layers of meaningful representation at the same time: a broad anthropological layer of embodied values that can be shared by all; the social layer of a community festivity limited to those actually involved; and the political layer of a more precise message about the present and the future of the social and political body.

During the opening event of the Peace of Utrecht Tercentenary on 13 April, these three layers were quite evident for the observer: the community festivity of the anniversary of the peace treaty was marked by a huge theatrical performance, combining music, acting, dancing and all the sensorial experiences that are involved in a mass manifestation, carrying anthropological values. The political layer was made visible in the play that was performed on the open-air stage by actors and soldiers. Surprisingly, the political message was wrapped up in a military staging, and the spectacle was named the Battle for the Peace, although the peace negotiation of 1713 deliberately was set far from the battlefields. But central to the theatrical performance as well as to the political message was the fire, combined with a play of lights and with a compelling musical accompaniment. Bonfires rising in the air from the top of the four watch towers that formed the centre of the stage and the fiery outbursts of the fireworks 
themselves concluded the performance: starting with a fiery imitation of the war violence, the fireworks advanced gradually over a quarter hour, climaxing in explosions of joy.

The sensorial experience of the present-day spectators must have come very close to what the bystanders may have felt during the 1713 fireworks. If we take, for example, the fireworks organized by the States General at The Hague on 14 June 1713, the similarity of the visual representations in pictures is striking, including the suggestion of smoke. Of course, we cannot smell the smoke of 1713 anymore, but this was one of the conditioning elements of that mass experience, along with the obsessive and penetrating sound of the repeated explosions. ${ }^{5}$ The 2013 trajectories of the rockets, fireballs, fire fountains and other implements of the spectacle correspond closely to those of 1713. Most of all, the constructed setting of the spectacle, the theatre or 'fireworks castle' as it was formerly called, appeals to a sense of recognition, to a retrieval of our centuries-old memory of the political meaning of fireworks for the community. The four watch towers and the city wall represented at the 2013 celebration were theatrical constructions which not only supported the launching platform of the fireworks, but surrounded it at the same time with a politically inspired framework. The representation that was embodied in this constructed frame guided the event's meaning: the victory of the peace negotiations was clearly linked to the urban war experience, and it was implicitly suggested that civilization, as opposed to the violence of war, comes from the politically regulated society of the urban Netherlands. This message reflected in a modern way the meanings purposely conveyed through their fireworks three centuries earlier by the city, provincial and state authorities of the early modern Dutch Republic.

\section{The Fireworks Castles}

For the 1713 celebration, the States General had chosen a triumphal arch of $160 \times 90$ feet in surface, and 5o feet high, as the centrepiece of the fireworks

5 Whereas most engravings of the fireworks published on the initiative of the organizers or by individual print sellers present a clear and detailed picture of the fireworks castle and the symbolic representations it conveys, the engraving Lust-park vande Vreede tussen de Hooge Bondgenooten ende Fransen, geslooten te Utrecht den 11 April en bevestigd den 12 Mey 1713 (Amsterdam: Abraham Allard, 1713) [Utrechts Archief, Historische Atlas: S 13.22], displaying the peace process in eight episodes, emphasizes in the last picture the repeated fire explosions and smoke curtains caused by the fireworks, hiding the view of the theatre itself. 


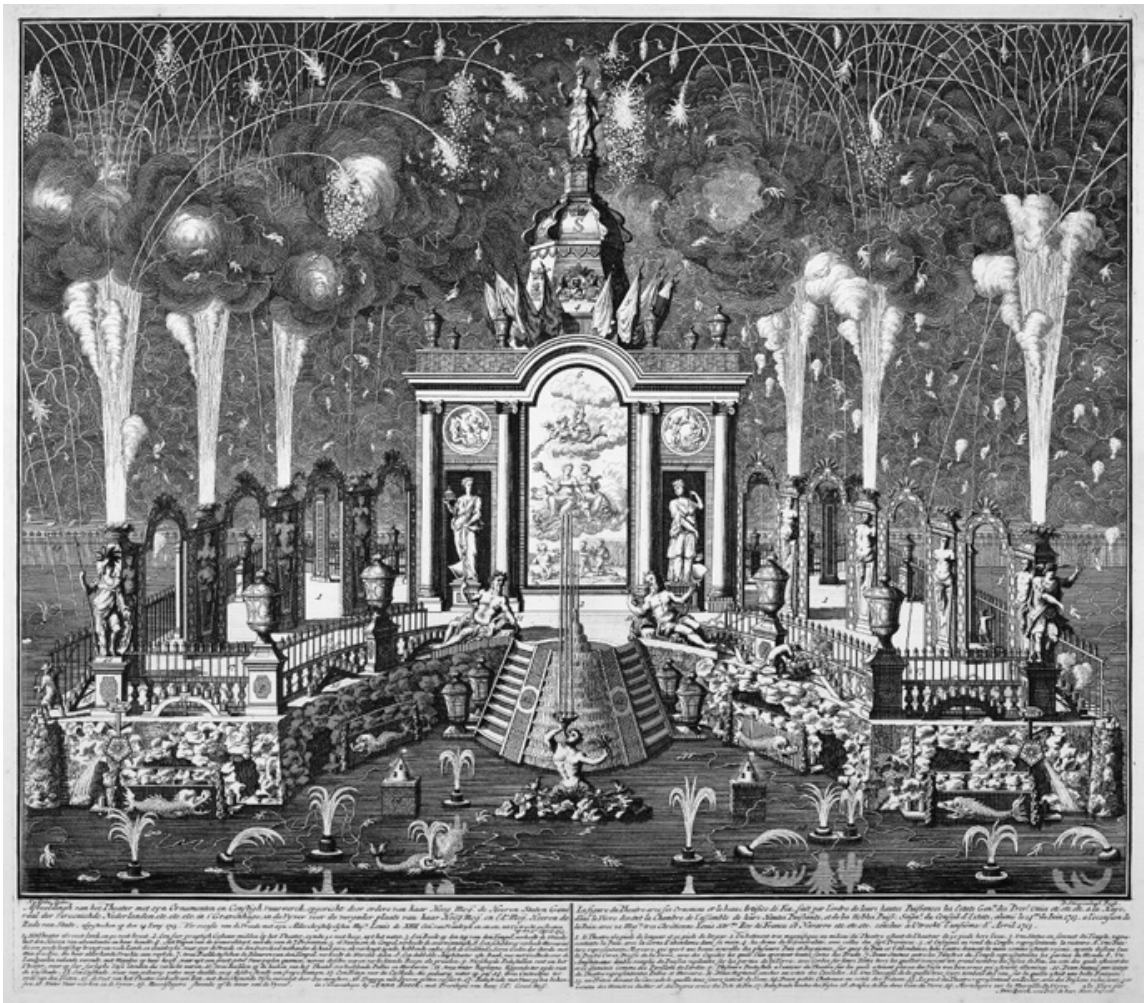

FIGURE 13.1 Afbeeldingh van het Theater met zyn Ornamenten en Constigh Vuurwerck opgericht door ordre van haar Hoog Mog. de Heeren Staten Generael der Vereenichde Nederlanden etc. etc. etc. in s'Gravenhage in de Vyver [...] afgestoken op den 14 Iuny 1713. Ter occasie van de Vrede met zyn Alderchristelyksten Maj.t Louis den XIIII. Con. van Vrankryck etc. etc. etc. tot Uytrecht geslooten op den 11 April 1713. Engraving by D. Stoopendaal after H. Pola (The Hague: Anna Beeck, 1713).

ATLAS VAN STOLK, ROTTERDAM

amphitheatre, whereas the States of Holland and West-Friesland had built a temple of similar size, $150 \times 109$ feet, and 85 feet high. Classical imagery dominated the representations on the castle of the States General (fig. 13.1). It was crowned by a huge statue of the deified Peace with the cornucopia, watching over the arms of the Union and of the seven Provinces, and surrounded by sixteen victory banners. In the centre of the castle was a huge painting of 'Mercury bringing the joyful message of peace and abundance to the many countries and realms involved, who hold out each other's hands, above Ceres and some minor deities who supply all kind of fruits', as described in the printed explanation for the general public. Two huge statues on both sides of this central 


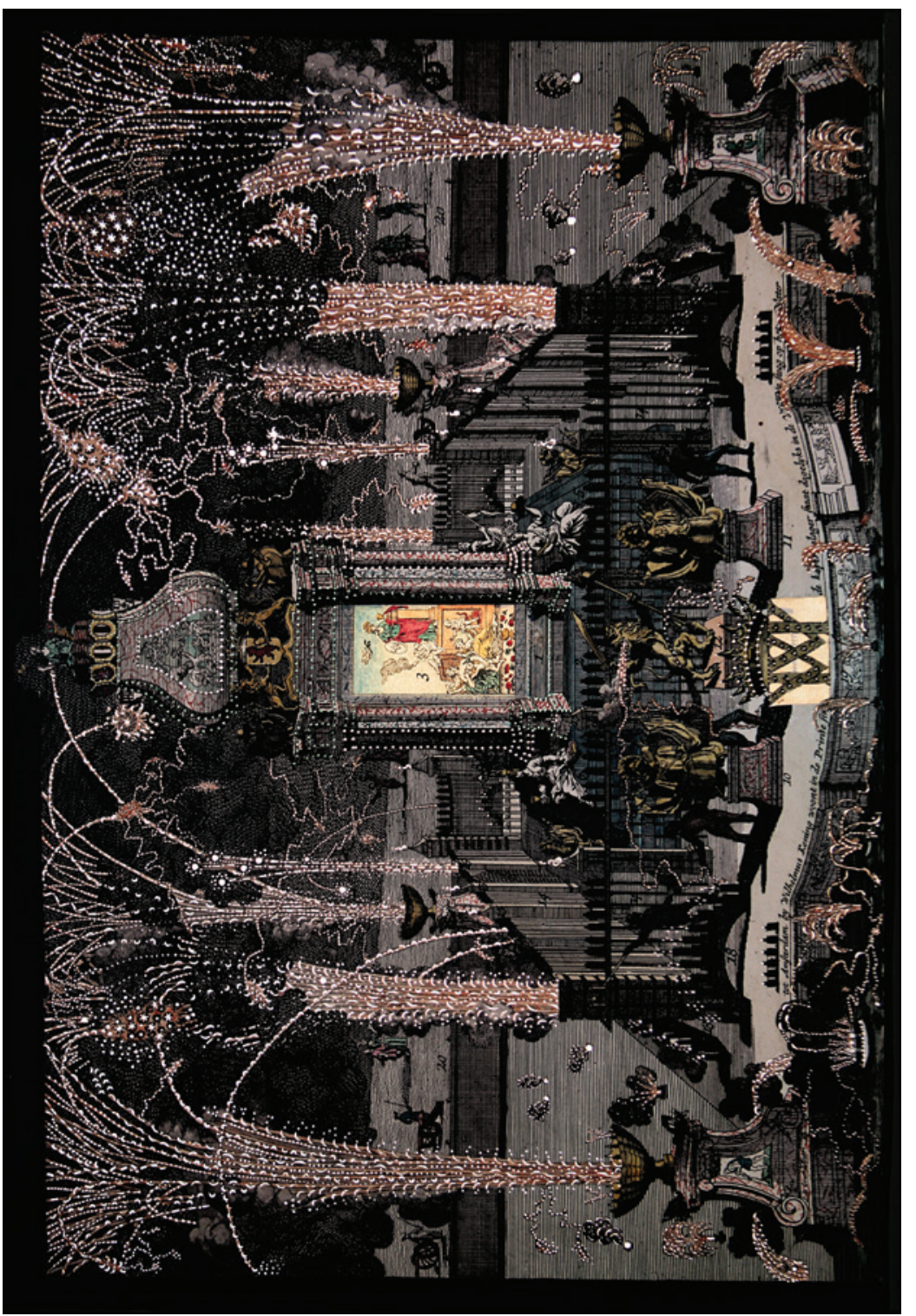

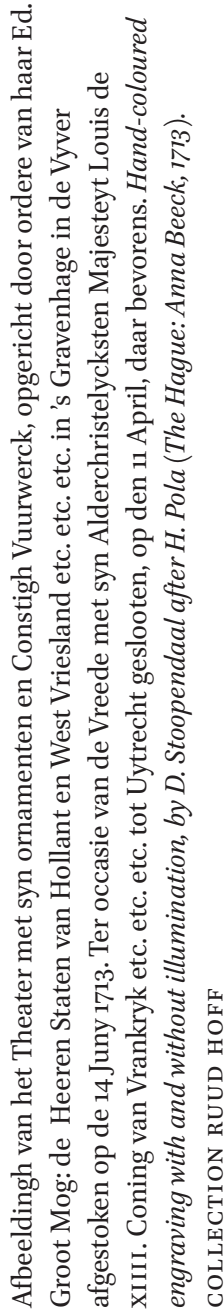

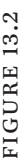




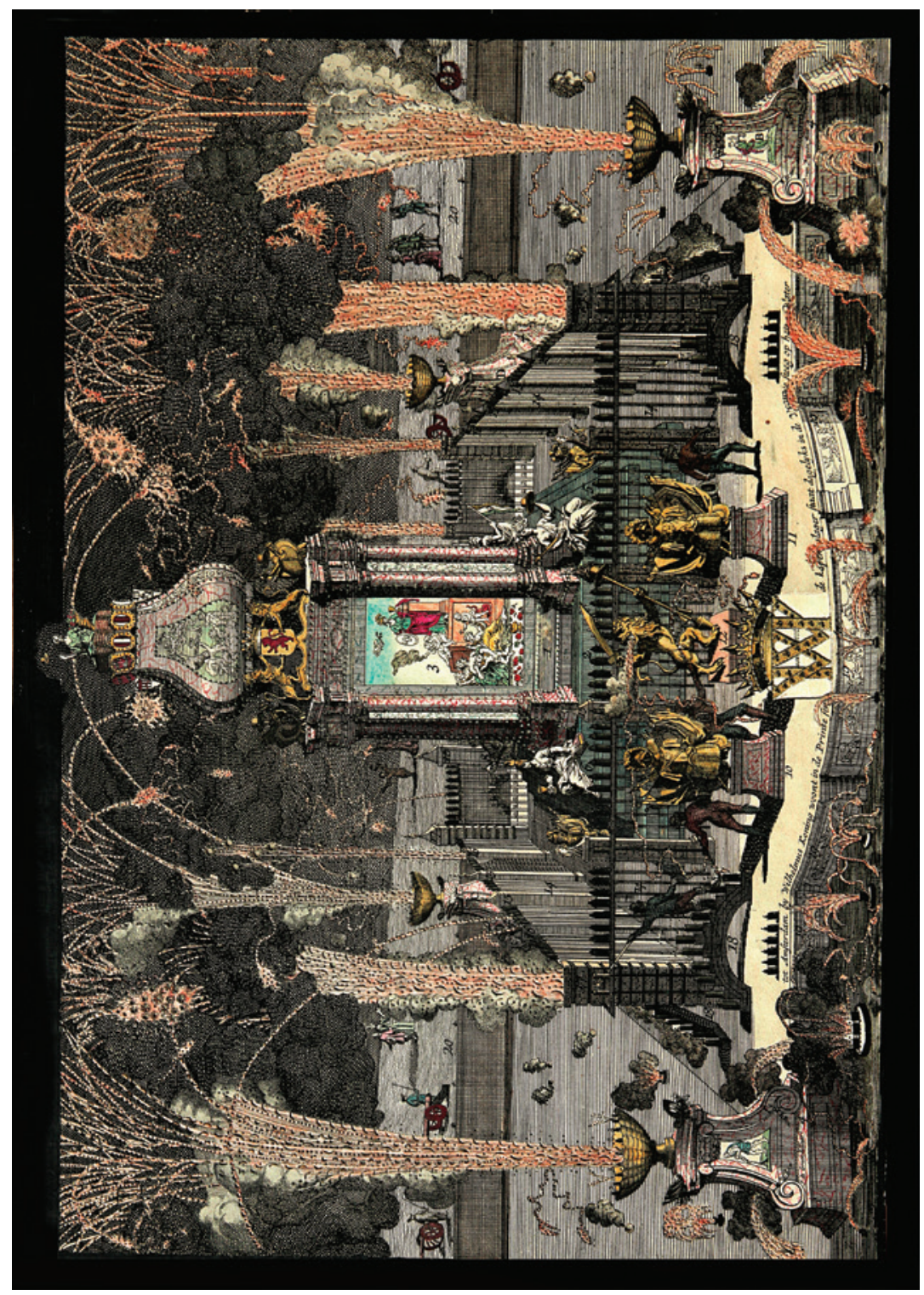


picture represented the continents (Europe and Asia?), Neptune and Triton embodied the oceans, whereas Pallas and again Mercury closed the aisles of the amphitheatre castle at its extremities. The castle of the States of Holland took the form of the temple of Janus, the doors of which had to be opened in wartime and closed in a period of peace (fig. 13.2). The metaphorical scenery was rather similar to that of the States General, but predictably the statue on top represented the Virgin of Holland raising on a stake the traditional Hat of Liberty, whereas, a bit surprisingly in this classical universe, the female figure in the centre depicted the (Christian) Faith, with the dove of peace, surmounted by the maxim Deo conf[idi] (My trust is in God). It is this religious element of the repertoire that points us to the deeper, inward-directed meaning of the fireworks imagery.

The Janus symbolism, expressing a final and hopefully definitive change of state, is visible in all the fireworks. This metaphor was, for instance, also applied by the municipality of The Hague on the façade of the Town Hall: the doors of the temple of war were closed in order to give way to Apollo and the Muses making music on behalf of the peace, to the Peace itself seated on its throne with the cornucopia, and to a cheerful Bacchus, drinking to the renewed arrival of fully loaded merchant ships. A popular song entitled Lof van de Vreugde Theaters (Praise of the Theatres of Joy) and written on the occasion of the Utrecht Peace stresses the political dimension of the scenery on the different theatres at The Hague: the Union of the Seven Provinces, the Janus metaphor, the urban pride of The Hague expressed in the figures of two storks (the local totem animal from the city arms) and the lion, as a symbol of courage. ${ }^{6}$ However, what is most striking in the visual language of the castles of the States General and the provincial States in The Hague is not the predictable general symbolism of the Union, the Dutch lion and the peace (the virgin of peace, the horn of abundance, the Dutch hat of freedom), and the classical metaphors, or, in The Hague as well as in Rotterdam and Leeuwarden, Mercurius as the symbol of a renewed commercial liberty, prosperity and abundance, but the moral dimensions of the representation they intend to transmit.

Indeed, the most explicit message expressed by the emblems and metaphors was not turned toward the international community or the outer world, but inner-directed, in a moral as well as a political register of a more topical nature. The statues on the corners of pedestal of the temple of the States of

6 This song on a melody by J. van Elsland (1717), printed in De Gekroonde Utrechtze Vreede (1718), was recorded in 2013 on the compact disc De Vrede van Utrecht (1713). Muziek uit de Spaanse Successieoorlog, performed by the Utrecht music ensemble Camerata Trajectina (cd Globe: $\mathrm{GLO}_{5256}$ ). 
Holland embodied the four main moral virtues: charity, justice, prudence, and courage, while the four figures surrounding the temple on top of the pedestal represented religion, freedom, commerce, and the arts. In the political register, both castles at The Hague were dominated by heraldry referring to the seven Provinces and, in the case of the States of Holland, to their sovereign rulers, i.e., the nobility and the eighteen voting towns that together composed the ruling assembly of Holland and West-Friesland. The arms of each town were exposed on top of the centrepiece and underscored by an appropriate device, either a traditional one, such as the ancient Vicit vim virtus for the city of Haarlem, the highly applicable Terra marique potentissima for the metropolis of Amsterdam, or newly made, suitable texts, such as Hostium per fulmina terror for Delft, seat of the provincial arsenal, or Bataviae nutrix, for cheese-making Edam (fig. 13.3).

The moral message was most clearly expressed in the maxims that were lavishly added to the different elements of the monuments and explained to the general public in the booklets and flyers produced for the occasion. Consider, for instance, phrases such as Patet Deum quaerentibus (Open for those who are in search of God) at the entrance of the temple of the States, Fax in mundo fluctuantis (A beacon for those who wander in the world) under the image of religion, or Illius in verba (I trust in God's Word alone) under that of the Bible, on top of the temple. They match similar statements on the liberation of the nation from slavery (!) in Non erit liberae reditus, on the universal blessings of the Dutch Republic imagined as a bee-hive, where the bees Sibi laborant et urbi (They work for themselves and for the whole world) or on the arrival of the East India fleet Hic plusquam vellus aureum (Better than the Golden Fleece) and on the union of faith and freedom Alterius altera poscit opem (They need each other's help). The whole imagery is summarized in the maxim Tantum religio potuit conferre bonorum (So many blessings has religion bestowed upon us), uniting in a single phrase the meaning of four objects: the hat of freedom, a well-filled purse, a book, and a try square, symbols of the fruitful union of politics, commerce, science and industry. Through such metaphors, the fireworks castles present themselves as instruments for the education of the nation

\section{Symbolic Language and Political Message}

Naturally the multi-layered character of the public festivities including a clearly voiced or visualized political meaning is not limited to the fireworks performances alone, nor is it characteristic of the Dutch Republic as such, although the visual and textual languages reflect, of course, Dutch idiosyncrasies. But more generally speaking, for the present-day observer the Peace 


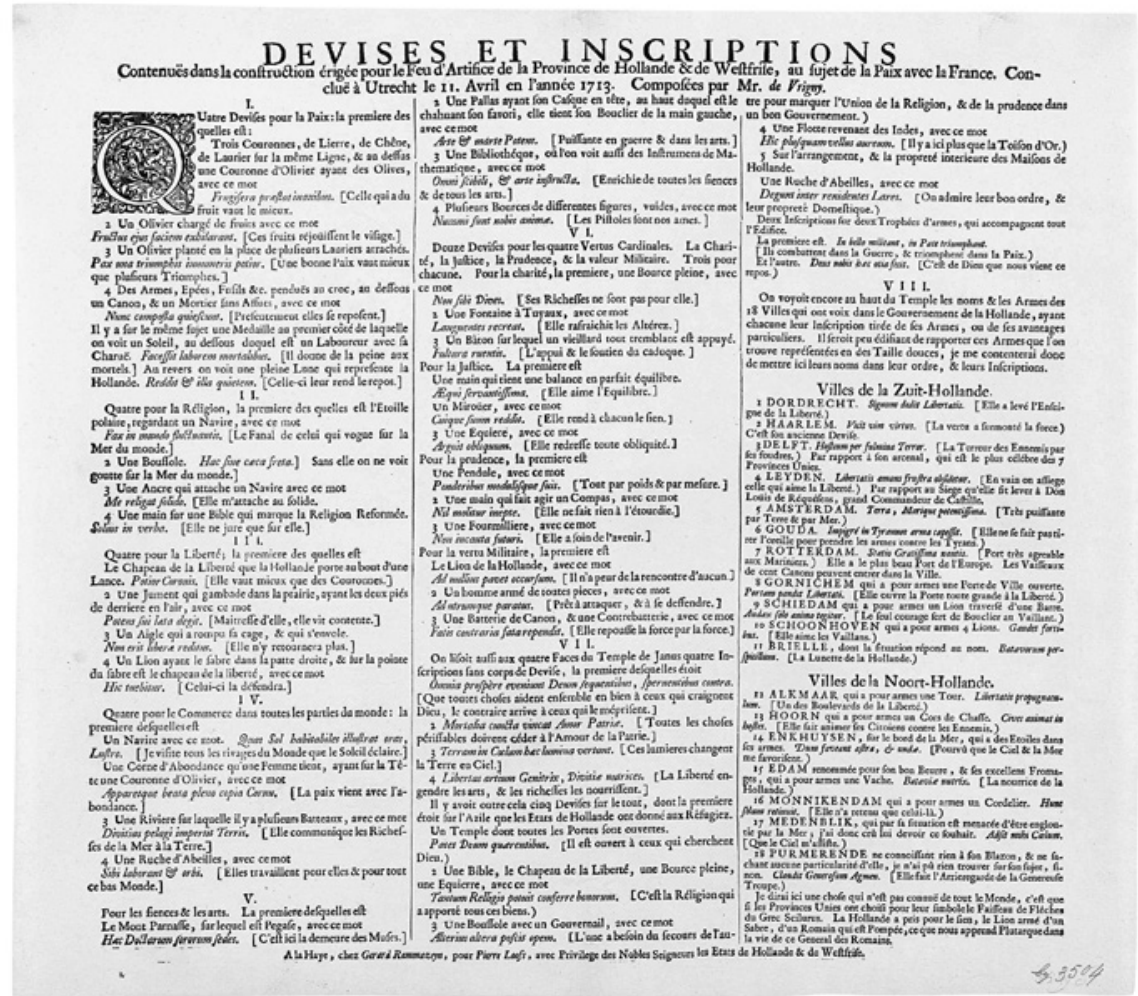

FIGURE 13.3 Devises et Inscriptions Contenuës dans la construction érigée pour le Feu d'Artifice de la Province de Hollande \& de Westfrise, au sujet de la Paix avec la France. Concluë à Utrecht le 11. Avril en l'année 1713. Composées par Mr. De Vrigny (The Hague: chez Gerard Rammazeyn, pour Pierre Loofs, s.a. [1713]). RIJKSMUSEUM AMSTERDAM

Treaty of Utrecht has become a multi-layered political fact in itself. Its longterm consequences are rather obvious, but by now the meanings embodied in the performances at the 1713 peace celebration are for us difficult to grasp. One of the reasons for this dissonance is the dominant place taken by the symbolic expressions of the peace communication. Of course, celebrations always carry symbolism. They communicate the multiple messages of the celebrated facts or events in symbolic languages known by the groups or communities addressed and liable to be decoded by them in order to be correctly understood and appropriated. After decoding, their elements must be selected and appropriated as meaningful for the community involved in the spectacle or intended by its organizers. Celebrations are passing and volatile. They are performed in a short time period, as instantaneous events in theatrical settings, 
but they carry messages with a long-term meaning. Therefore the language used by the celebration itself normally is metaphorical because metaphors belong to symbolic systems vested in the community's history. Visual, textual and sensorial metaphors appeal to well-known and coherent registers of memory and allow a compression of the intended meaning into simple representations that can be easily performed but long remembered. Fireworks as a public spectacle were visually accessible to everyone and indeed unavoidable for the common citizen on the street. They were immediately experienced as a sensorial event and occupied therefore a particular place in the performance of public celebrations.

However, the rich content of such metaphoric messages is not immediately legible or understandable in its full depth, not for us or for the spectator of the year 1713. The message had to be decoded and translated into other registers of understanding. For instance, political messages were wrapped up in the visual and textual languages of the classical Antiquity or of the ancient pantheon. Heroes, myths and emblematic figures were the key elements of these languages that needed translation into the everyday realities of the world of 1713 . At the same time, metaphors permit us to transcend the limits of topical representation and of the day-to-day experience because they are applicable to any similar event in any time period, provided that the register of understanding is still working in the community's memory. But for most of us the language of classical Antiquity, of the ancient mythological pantheon and even of the biblical metaphors is no longer at the core of our collective memory. It has lost its validity for our life experience, and we are no longer able to recognize spontaneously its symbolic values. Therefore, although the procedures were the same as in 1713 , the 2013 fireworks had to adopt a new metaphoric language.

The peace celebration of 1713 was marked by a remarkably rich number of performances and representations with a symbolic charge or of a metaphorical character: festivities, balls, dinners, spectacles, musical performances, religious services, celebratory poems, popular plays, and so on. Yet in the symbolic register the fireworks stand out, both in quantity and in quality. Probably no peace celebration was accompanied by such a rich series of fireworks in so many cities in the Netherlands and beyond. Only the 1648 Peace of Westphalia, celebrated across Europe, may have had a similar impact, but it has left fewer visual traces in historical memory. The authorities responsible for the fireworks were quite conscious of the weight these fireworks had in the public opinion and of the educational dimension attached to their political programme. Therefore, fireworks were not simply decided by the authorities themselves or discussed in the representative bodies, they were also publicly announced and interpreted, and the best designers were engaged. 


\section{Fireworks Traditions}

Behind the immediate, crude experience of the fireworks as a public event, the constructions which formed the support and the fixed background of the volatile fireworks told another, symbolic story meant for those who were able to decode it politically. As early as 1649, a satirical description was published of such an elaborate symbolic castle allegedly to be built at The Hague for the fireworks produced for the marriage of the king of Spain and the daughter of the Emperor. ${ }^{7}$ Such texts show how notorious the typical decoration programmes of the public fireworks already were. Around 1700, their design in the Dutch Republic was entrusted to reputed architects and artists, such as the Huguenot refugee Daniel Marot, the architect Pieter Roman, the engraver Pierre Loofs, or the versatile artist Romeyn de Hooghe, while the execution was the work of technical specialists in the service of the authorities. Broadsheets, printed images, explanatory booklets and flyers documenting the fireworks castles down to their tiniest details and explaining the elements of the constructions were published before the fireworks or sold during and after the performance in order to help the recording of the celebration, the preservation and structuring of the public memory, and the trickling-down of the message. In Friesland, for instance, the learned bookseller François Halma published an extensive explanation of the Leeuwarden fireworks, probably authorized by the States of that province. ${ }^{8}$ They helped the public to understand their political and social layers of meaning. In what follows, I shall concentrate on some of these forms of representation and decoding, and try to understand why the political messages were brought in that utterly complicated way.

Ever since the very first political representation underpinned fireworks in late-sixteenth-century Europe, the lay-out of the scene had been fixed: fireworks had to be set off from a platform showing a fixed construction, the 'castle', that by its shape, mostly as a theatre or a stage, and still more by the images and pictures attached to it, conveyed a precise political, social, cultural and moral message for the community in a metaphorical language, in fact the language that was derived from the classical imagery characteristic for the edu-

7 Modelle ou project du feu d'artifice qui se doibt faire a la Haye le Mardy 16. Nov. pour la rejoüyssance sur le mariage du Roy Catholique \& la Serenissime Archiduchesse fille de l'Empereur (Brussels: s.n., 1649), 8 p. [The Hague, Koninklijke Bibliotheek: Pamphlet 646o].

8 F. Halmaes Vredezang den Edelen Mogenden Heeren Staten van Frieslandt eerbiedigst toegewydt, by d'afkondiging van den gesloten Vrede den XIV. Van Zomermaandt, MDCCXIII (Amsterdam: Johannes Oosterwyk, 1713) [The Hague, Koninklijke Bibliotheek: Pamphlet 16184]. 
cation of the political and learned elites. ${ }^{9}$ The fire itself had to spring off from the major elements of the construction, quite often in a combination of fixed bonfires on top of pillars, pinnacles or other decorative elements of the castle, and of repeated discharges of moving fireworks behind or beside the theatre or the castle. In fact, two basic formulas imposed themselves quickly for the ideal material support: the temple of peace or joy and the triumphal arch. Most firework architects made a choice between these two formulas, probably submitting them to their principal before the actual construction took place and the decoration programme was elaborated in detail. In the Dutch Republic, the major firework spectacles were set up as waterworks, but the association of water and fire, two opposite elements involving an anthropological value in itself, was also popular elsewhere. At Amsterdam, the Amstel or one of the main canals could be adopted for the central stage of the fireworks, while at Rotterdam a platform could be constructed on the river Meuse. But large urban spaces would also do. The Leeuwarden fireworks construction of 1713 was set up on the Marktveld as were the less elaborate fireworks castle on the Grote Markt at Haarlem and the fiery decorations in front of the Town Hall of The Hague (fig. 13.4).

The two governmental fireworks of 14 June 1713 in The Hague were set up in the Hofvijver, in front of the meeting halls of the States General and of the States of Holland and West-Friesland. This huge pond offered the most suitable setting for fireworks, not only because of its eminently significant political situation but also because it could host many spectators along its three banks and provide relative safety. Indeed, fireworks could be dangerous, even for those in power: witness the famous injury suffered by the Polish king Ladislas IV Vasa from a rocket as he watched fireworks from a window of his palace in 1636 . Some fireworks were not intended for the celebration of peace but of war and conquest. On the birthday of the French king Louis XIV, 5 September 1673, the municipal council of Marseille in Southern France, for instance, set off a huge fireworks showing how the monarch had taken the city of Maastricht at the end of June of that year after its memorable siege by Vauban-revived in our long-term memory by Alexandre Dumas' exaltation of the heroic death of musketeer captain d'Artagnan. Apparently no image remains of the Marseille fireworks castle, but according to its published description it represented a victorious King Louis launching his lightning on the city of Maastricht which

9 The Haags Historisch Museum still conserves the wooden model made by Mrs. ValkenaerDuyvensteijn, after the design by court architect Pieter de Swart, of the theatre for the fireworks in the Hofvijver in The Hague on 13 June 1749, at the celebration of the Peace of Aix-la-Chapelle (18 October 1748). 


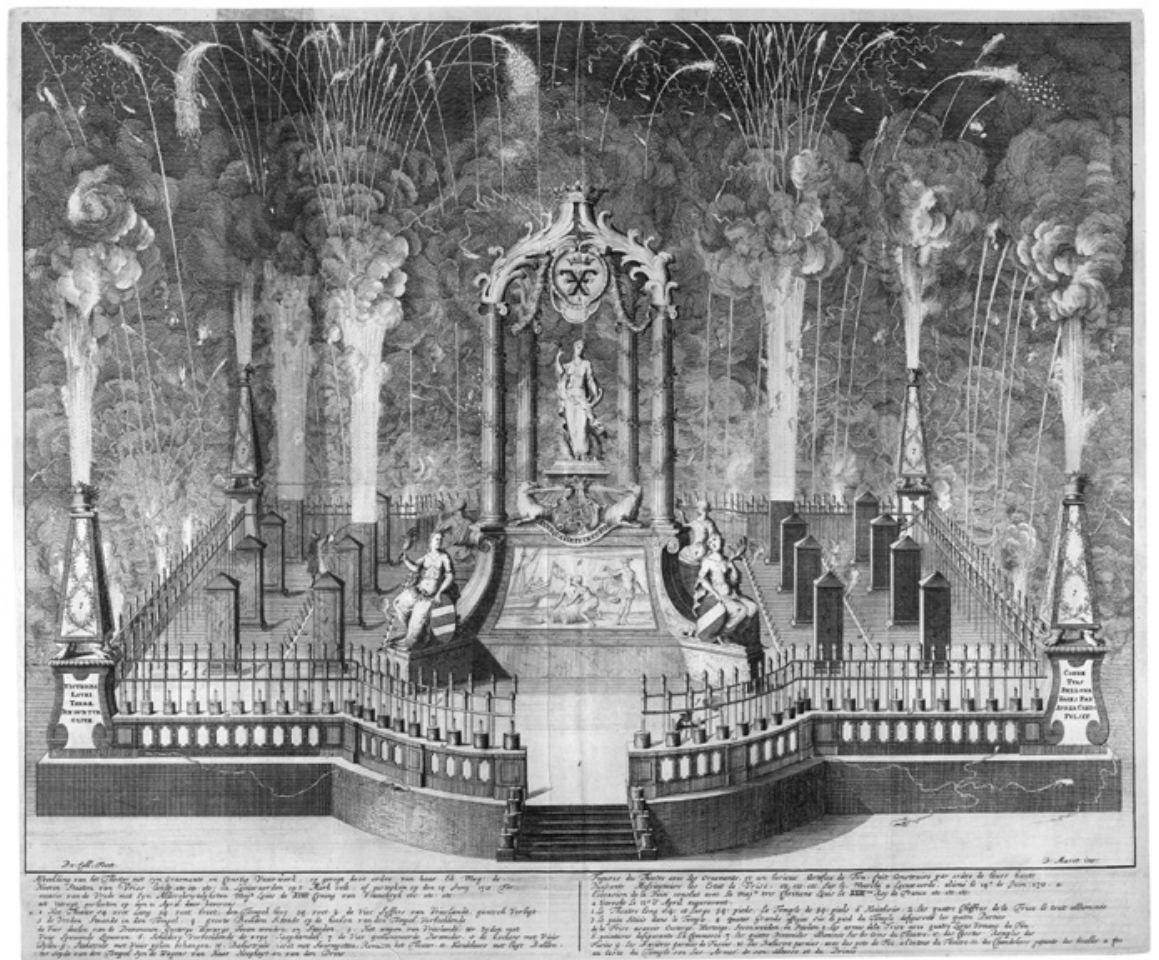

FIGURE 13.4 Afbeelding van het Theater met syn Ornemente en Constig Vuurwerk, opgeregt door ordre van haer Ed. Mog. de Heeren Staeten van Vrieslandt etc. etc. etc. in Leeuwaerden op 't Markvelt, afgestooken op den 14 Junij 1713. Ter occasie van de Vrede met Syn Alderchristelyksten Maj. Louis de XIIII Coning van Vranckryck etc. etc. etc. Engraving by P. van Call after D. Marot TRESOAR, LEEUWARDEN

was then metaphorically consumed, while images of humiliated towns, such as Utrecht, Nijmegen and other conquered cities, surrounded the central scene. ${ }^{10}$

Since fireworks were visible for everyone and constituted the ultimate social sensation, they were a matter of public interest. The physical dangers involved required regulation or intervention by the public authorities, as did the considerable cost of the representation. There have, of course, been private fireworks initiatives, either for celebratory or for publicity reasons, but obviously such private castles were of a less complicated design and their decoration

10 Triomphe de Louis XIV dans Marseille, pour ses conquestes dans la Hollande. Qui paroistra le 5. Septembre 1673, jour de sa naissance (Marseille: chez Charles Brebion, 1673), 9 p. [Paris, BNF: $\left.8^{\circ} \mathrm{Lk}^{7} \cdot 50213\right]$. 
programmes, though still highly learned and often barely accessible to the common spectator, were of a lower metaphorical level. The most sensational private fireworks were those prepared by the student associations of Utrecht and Leiden for the prince of Orange in 1747 and 1766 , and at the centenaries of their own universities, founded in 1575 and 1636 . The students may have felt challenged to triumphantly display their level of learning to the common people, and those of 1736 in Utrecht made up for the regrettable negligence of the city council in 1713 .

\section{Politicization}

But generally speaking, technical, financial and management factors limited fireworks to the domain of public decision-making. Although the discovery of the full potential of celebratory or recreational fireworks for political propaganda and social education has taken some time, public authorities came gradually to perceive fireworks as an excellent means for transmitting a public message intended for the whole population. The first visually documented fireworks still remain close to the traditional bonfires. They express joy and celebrate facts, not intentions. They stress the spectacular effects of the fire itself, the explosions of fire and the lightning, not, or to a lesser extent, the message attached to the event. The symbolism of the castle that supported the fireworks remained long implicit. The Paris fireworks of 1642 for the king and queen of France, the Nuremberg fireworks for the Peace of Westphalia at the 1649 and $165^{\circ}$ Friedensmähle, ${ }^{11}$ and the Dutch fireworks for the 1654 victories over the English fleet, preceding the first Peace of Westminster, were essentially huge bonfires, at best a bunch or row of exploding rockets. Their meaning was in the event itself, rather than in the moral message which the celebration was able to convey. The 1649 Osnabruck fireworks apparently lasted two hours, but their Theatrum Ceremoniale just shows the traditional political metaphors in a purely emphatic mode: the maxim Vivat Pax surrounded by a dragon and a crowned eagle holding a sceptre and a sword.

Yet the use of fireworks was already changing. As early as 1585 , on the occasion of the ducal marriage at Dusseldorf, a festival extended over three evenings combined a series of still rather simple celebratory fireworks with elaborate theatrical performances set against a metaphorical background and

11 Sigmund von Birken, Teutscher Kriegs Ab- und Friedenseinzug (Nuremberg: s.n., 1650), 40 p. Accessed 1 November 2013. http://www.mdz-nbn-resolving.de/urn/resolver.pl?urn =urn:nbn:de:bvb:12-bsb105139o11. 
representing different stages of the eternal fight between good and evil, and indeed between the religious confessions, amply explained in a book drafted by the duke's Catholic councillor Theodorus (or Diederich) Graminaeus and illustrated by the famous engraver Franz Hogenberg. ${ }^{12}$ This festival must have set the tone for further developments. Fireworks henceforth became an integral part of European court culture and a much cherished privilege of the prince.

From the 1670 on, political symbolism literally exploded in the fireworks, due to a combination of factors: the emancipation of a truly secular festival tradition, new fashions in the arts, the breakthrough of formal classicism in public representation, and the influence of French baroque court culture. After the Italian Renaissance, the heavy rhetorical idiom and the rich but rapidly standardized metaphorical language of French classicism exercised a tremendous influence on the design of the public space and of public performances in Europe. In fact, rather quickly public manifestations, in particular fireworks, adopted everywhere in Europe a similar metaphorical language and as such became universally understandable: Mercury for the fruits of commerce, Mars for war, Pallas for wisdom, Ceres for agriculture, Neptune for maritime navigation, and so on. Hence, without the help of published explications providing a topical interpretation it is on a European scale difficult to distinguish each event's unique meaning. Yet behind these global symbols, local and national realities steered their combination, their meaning and their interpretation. It was the gradual discovery of fireworks castles as privileged conveyors of political messages for the global population that made them popular among the ruling elites but diversified at the same time their composition and the messages which the common imagery was intended to inculcate in the minds of the locals.

In the Dutch Republic, Romeyn de Hooghe was one of the great creators and purveyors of that increasing instrumental use of fireworks at the service of the nation-state. Born in 1645, he worked as a gifted engraver, a poet, and a politically engaged author in Amsterdam and after 1682 in Haarlem, until his death in 1708. In the 'pamphlet wars' of these decades, he took decidedly sides in favour of the Orange party and Protestant policy, and against France and

12 Diederich Graminaeus, Beschreibung derer Fürstlicher Güligscher \&c. Hochzeit, so im jahr Christi tausent fünffhundert achtzig füff am sechszehenden Junij vnd nechstfolgenden acht tagen zu Düsseldorff mit grossen freuden, Fürstlichen Triumph vnd herrligkeit gehalten worden (Cologne: s.n., 1587), 246 p. [reprint Düsseldorf: Verlag Hans Marcus, 1982]. 
the Catholics. ${ }^{13}$ Many fireworks engravings bear his name, and it certainly is no coincidence that he was asked on several occasions to design public fireworks for state affairs himself. Some of the most elaborate etchings of such performances are of his making, for instance those related to the coronation of Prince William III of Orange and Mary Stuart as rulers of England in 1689 and the solemn entries of the king-stadholder in different cities of the Dutch Republic during the following years. It is precisely in the course of his career that we discover the changing trend and the increasing tendency to attach political intentions and moral messages to the fireworks castles. John Amos Comenius had already stressed the moral meaning of exploding and falling rockets, as signs of pride, conversion and repentance. An engraving representing the fireworks set off in London, in several Dutch towns (Leiden, Maastricht, Haarlem, Amsterdam) and in Hamburg at William \& Mary's coronation on 21 April 1689 shows in fact a combination of traditional bonfires and of more modern fireworks of a rather complicated pyrotechnic character. ${ }^{14} \mathrm{~A}$ view, published separately, by Romeyn de Hooghe of the fireworks displayed in his home town Haarlem on that occasion, shows a spectacular but still rather traditional display of a long string of bonfires circling around three constructions identified by the royal emblems and initials. In spite of the great number of formal or literal references to the king or the coronation, no great decoration programme going beyond the mere mention of the event and its protagonists is visible in those pictures, nor can we detect a general design to which the individual fireworks in particular places were subordinate. ${ }^{15}$ It is just one enormous, multi-located and multifaceted explosion of intended public rejoicing. The Amsterdam fireworks for William and Mary in April 1689 show this quite clearly: the celebration is exhibited as a masterly and captivating pyrotechnic spectacle uniting bonfires and fireworks but destitute of any moral message other than the political virtue of the monarchy in the confederate republic that the United Provinces still were. The message remains implicit, even if many spectators must have understood it quite well.

13 On his work as en engraver: Henk van Nierop, et al., Romeyn de Hooghe: de verbeelding van de late Gouden Eeuw (Zwolle: Waanders, 2008).

14 Vreugde-vuuren. Tot Londen, en in verscheidene Steeden van Holland en Braband, en tot Hamburg; over de Krooning van haare Majesteyten van Groot Britannien, Willem de Derde, en Maria, Ontstooken [April 21, 1689], engraving after Romeyn de Hooghe [Rotterdam, Atlas van Stolk, $\mathrm{n}^{\circ} 2787$ (inv. $\mathrm{n}^{\circ} 44624$ )].

15 Vuur-staken en Vreugt-bewysen, door de Ed. Agtb. Heeren vande Regeering tot Haarlem, op de Markt, Toorens, etc. den 21 April 1689, engraving after Romeyn de Hooghe [Rotterdam, Atlas van Stolk, inv. $\left.\mathrm{n}^{\circ} 36900\right]$. 
Subsequent fireworks in the last decade of the seventeenth century put an ever greater stress on the visualization of the political message in metaphorical images. The 1691 entry of the king-stadholder into The Hague shows the first signs of a pervasion of the spectacle by barely hidden patriotic meanings: the motto on the fireworks castle, the metaphorical lion, and the initials of the royal couple and their crown. Eight values of the Dutch Republic are visualized on the four faces of two columns, the most visible being the two key words of its historical identity: religio and libertas, placed on the front side of the castle. Unsurprisingly, these emblems and texts represent the common knowledge and the broad political consciousness of the well-schooled part of the Dutch bourgeoisie and in particular of its upper layers, without any indication of resistance or subversion.

Virtually the same observation holds for the fireworks performed for the reduction of the castle of Namur, four years later, and that in honour of the Russian embassy accompanying Tsar Peter the Great to Amsterdam in 1697. They show essentially the uncomplicated pleasure of a great pyrotechnical prowess around a barely visible minimum of symbolic representation, included in a rather traditional castle - a spectacle that was undoubtedly adapted to the still rather modest culture of the young tsar. However, a considerable change now occurs in the sphere of the publicity surrounding the fireworks. Henceforth, the published images of the fireworks contain not only the customary caption stating their actual and historical meaning, but they provide also a detailed description of the castle, the metaphorical elements it contains, and the meanings that should be attached to them.

In fact, around the turn of the seventeenth century the ideal fireworks performance would consist of a shrewd combination of a recreational spectacle and an educational show of a political nature, to be experienced de visu and in actu by the spectators with all the senses of the human body and to be remembered and reflected on afterwards, in the search for new, other, or at first sight hidden meanings. Fireworks become now primarily an instrument of topdown public communication. Henceforth the third layer, that of political consciousness, assumes a growing importance. ${ }^{16}$ The fireworks are from now on

16 A similar evolution has marked the literary production of that period, according to W. van Ravesteyn, 'Iets over politieke poëzie in het begin der achttiende eeuw,' Rotterdamsch Jaarboekje v, 4 (1946): 49-65. Excellent examples are the learned address by the Utrecht history professor Petrus Burmannus (Pieter Burman), Oratio de Pace inter potentissimum Galliarum regem \& praepotentes Foederati Belgii Ordines composita (Utrecht: G. van de Water, 1713), and the popular peace poem by the Haarlem weaver Jan van Gijsen, Vree bazuyn, toegepast, op de algemeene dank, vuur en vreugden dag: 
one of the privileged instruments of the perfect politician, and, for that matter, of the perfect ideologist. Their very cost and rarity makes them an object of choice for a thorough political education.

After the turn of the century things continue therefore to change quickly. The ideological message grows in political importance and assumes an ever greater role in the elaboration of the fireworks as a multifaceted spectacle. The fireworks set off in the Hofvijver in The Hague on 13 December 1702, created by Daniel Marot, on the occasion of the victory of the Anglo-Dutch fleet in the bay of Vigo in Spain, show a clear rhetorical effort to transmit and inculcate the values of the victorious captains of the fleet. In this case, we know that a special committee of the States prepared the design of the fireworks. The texts and images on the pedestals of the fireworks castle combine bilingual references to the antique deities Neptune, Hercules, Mars and Pallas, with metaphorical scenes and animals, and well-known Latin devices. In fact, all these elements were familiar to the educated citizen of that time, schooled in Latin and still familiar with the metaphorical language of classical Antiquity. It is their combination that must surprise him, convey a new, precise message, and make him think about the happy state of public affairs and the glory of those in power. ${ }^{17}$

\section{3: The Zenith of Political Symbolism}

The 1713 fireworks set off for the celebration of the Peace Treaty of Utrecht probably represent the zenith of this evolution and the most advanced development of the educational and patriotic dimension of the art of pyrotechnics. ${ }^{18}$ As the engraving that unites in a single image the different fireworks of 14 June 1713 shows, they may appear as one great political design, a common, pan-republican enterprise of all the public authorities involved, endowed with a single political meaning: celebrating the nation in all its political dimensions. The differences in the lay-out of the fireworks are clearly linked to the level of authority of the respective organizers and their financial resources: urban fireworks like those set up at Haarlem or even by the municipality of The Hague were of a much simpler design than those of the provincial States of Holland and Friesland or

uytgeschreeven tegens den 14. Junij, 1713 (Amsterdam: J. van Egmont, 1713) [copies in the Library of the University of Amsterdam].

17 C.W. Fock, 'Vuurwerk op de Haagse vijver in 1702,' Bulletin van het Rijksmuseum 16 (1968): 122-129.

18 See for the Dutch engravings concerning the 1713 fireworks also my essay 'Utrechts vreugdevuur: masker voor 's Lands neergang?' De Achtttiende Eeuw 40:2 (2008): 5-20. 


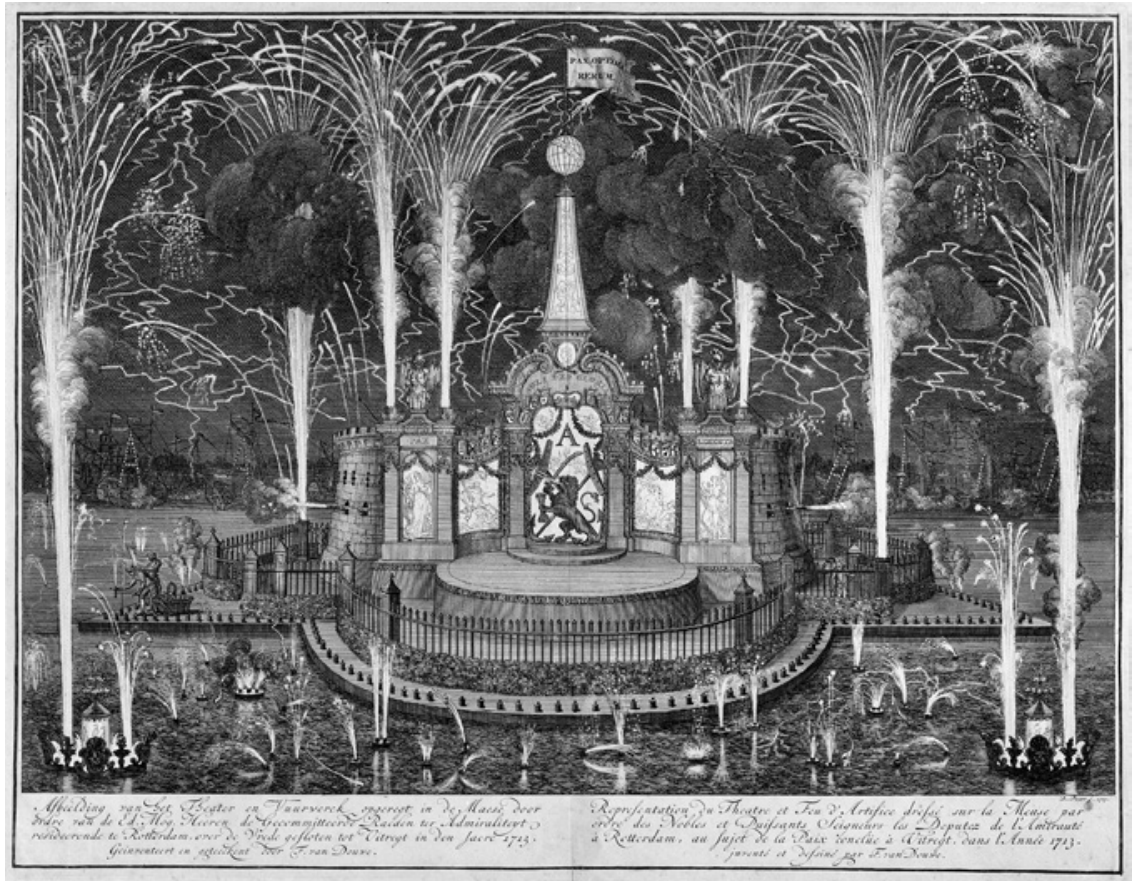

FIGURE 13.5 Afbeelding van het Theater en Vuurwerck opgeregt in de Maese door ordre van de Ed. Mog. Heeren de Gecommitteerde Raden ter Admiraliteyt resideerende te Rotterdam over de Vrede gesloten tot Uitregt in den Jaere 1713. Engraving by B. Picart after F. van Douwe (s.l., 1713). GEMEENTEARCHIEF ROTTERDAM

of the important Admiralty in the booming commercial town of Rotterdam (fig. 13.5). The urban fireworks address the common people and just want to provide a celebratory message of joy and conviviality, whereas the States use the occasion to tell a story and pass on a message of authority, power or policy. ${ }^{19}$ After 1713 fireworks become common practice in Europe for every possible public celebration and their organization breaks away from the semi-monopoly

19 A naughty narrative on the debauchery characterizing the daily life of the plenipotentiaries at Utrecht during the peace negotiations: Casimir [= Augustin] Freschot, Histoire amoureuse et badine du congrès et de la ville d'Utrecht (Liège: Jacob Le Doux, 1713), to confront with the analysis of the events by Lucien Bély, 'Utrecht, un théâtre pour la paix,' in W. Frijhoff, O. Moorman van Kappen (eds.), Les Pays-Bas et la France des guerres de religion à la création de la République Batave (Nijmegen: Gerard Noodt Instituut, 1993), 53-76; a Dutch translation of Freschot's text has been published by Erik Tigelaar and Roland Fagel (Hilversum: Verloren, 2013). 
of the public authorities, but rarely do they rise to the same level of emblematic riches and educational effort for a greater political consciousness. Imperceptibly the recreational element, one of the basic dimensions of the earliest fireworks, again triumphs over the educational dimension and prevails over the political goals. In that sense too, the Peace Treaty of Utrecht marks a summit and at the same time a turning-point in the art of representation. On the other hand, although a comparative study of all the fireworks in early modern Europe remains to be accomplished, the available evidence shows rather clearly that the Dutch fireworks occupied at that time a special place in the art of public recreational imagery. They excelled in their scholarly, perfectly reasoned use of emblematic scenery and in their educational efforts, and as such exceeded by far the fireworks displays of other countries, such as England, France or Italy, in spite of the latter country's pyrotechnical excellence. Although the real impact of such performances on mass mentalities remains of course questionable, they testify to a very high level of political consciousness of their inventors and to the conviction that through these new forms of public representation the citizens would be able to assimilate new images and new meanings, and would pledge a greater political commitment to the public cause.

Admittedly the city of Utrecht itself was not really in the forefront of this evolution. Surprised that all the other major cities of the Dutch Republic almost simultaneously organized fireworks for the celebration of the Utrecht Peace, some historians have attributed several images of fireworks to Utrecht for which no such initiative was known. It is still striking that the city which had so greatly benefited from the peace negotiations did not really invest in performances celebrating the outcome of the peace process, and apparently not at all in fireworks. One of the reasons may have been that the city council traditionally operated under much pressure from the church council, which in Utrecht for many decades was of a stern, orthodox persuasion in the line of Gisbertus Voetius, the former Utrecht professor of theology known as the 'Pope of the Reformed'.

In the course of the seventeenth century the Utrecht ministers, elders and deacons became radically opposed to any form of public rejoicings and more generally to whatever resembled theatrical representation, be it comedy or tragedy, all of which were considered as devilish art. When in December 1711 Utrecht was selected as the place where the peace negotiation were to be carried out, the problem of the social events and the recreational activities of the delegates became urgent. The town had to be attractive in order to favour a harmonious climate. Theatre was essential, as were public music performances, dances and balls for the high representatives and their company. Earlier in that 
year, the question of the theatre had been put on the public agenda by Pieter Burman, professor of history, eloquence and politics at Utrecht University, who argued against the Utrecht church council that remained firmly opposed to any public plays. On 6 June 1713 the city council decided finally to proclaim the Peace publicly on 14 June, after the first predication, and to authorize the burgomasters 'to regulate the signs and demonstrations of joy in front of the town hall, in the city and in the canals' - a decision that probably implied more an interest in control than an expansion of relief and pleasure. At any rate, no fireworks are known to have been set off in Utrecht on that date.

\section{Celebrating the Nation}

Outside Utrecht, in the national centre of political power The Hague, a combination of fireworks was organized that had to show an equal commitment to the peace by the three layers of political power traditionally united in a body called the Society of The Hague, i.e., the States General of the United Provinces, the States of the province of Holland, and the town council of The Hague itself. The States General fixed the date of 14 June for the whole country as a formal day of thanksgiving and prayer, free of working obligations, and therefore fit for all kinds of festivities. The three political bodies in The Hague made an agreement for the set-up of the fireworks and their metaphorical content, entrusting the formulation of the inscriptions and devices to a French Huguenot refugee familiar with the language of classical representation, Philippe de Vrigny. ${ }^{20}$ The semantic riches of each of the three representations reflects with precision the status of the organizing bodies: the municipality of The Hague contented itself with the sumptuous illumination of the front of the town hall in an allegorical

Verhael en uytleg van de twee uytmuntende Vuurwerken, zo van Haer Ed.Gr.Mog. de Heeren Staaten van Holland en West-Vriesland, als van haer Ho.Mog. de Heeren Staaten Generaal der Vereenigde Nederlanden, met goet succes aengestoken op den 14. Junij 1713...(The Hague: Pieter Husson, 1713), 26 p. [The Hague, Koninklijke Bibliotheek: Pamphlet 16175]. French version: Devises et inscriptions contenües dans la construction érigée pour le Feu d'Artifice de la Province de Hollande \& de Westfrise, au sujet de la Pai avec la France. Concluë à Utrecht le 11. Avril en l'année 1713. Composées par Mr. De Vrigny [The Hague, Royal Library: Pamphlet 16177]. The most important engravings of the 1713 Dutch fireworks are listed in Frederik Muller, De Nederlandsche geschiedenis in platen. Beredeneerde beschrijving van Nederlandsche historieplaten, zinneprenten en historische kaarten (4 vol.; Amsterdam: Frederik Muller, 1863-1870; reprint Amsterdam: N. Israel, 1970), II, n, 3497-3513, and in the printed catalogue of the Rotterdam Atlas van Stolk, IV, n, 3415-3430, to which the unpublished descriptions S 1710/56-64 have to be added from www.atlasvanstolk.nl. 
setting, whereas the States General and the States of Holland built their magnificent fireworks castles in the Hofvijver, the pond in front of the government quarter. Naturally, that of the States of Holland was the smaller and simpler of the two. In the pond, the fireworks theatre of the States General occupied the place of honour in front of the Mauritshuis; the peace negotiation delegates were invited to enjoy these fireworks from the windows of that urban palace. The front side of the fireworks castle was therefore turned away from the mass of the spectators on the three other sides of the pond, a disposition that made it still more necessary to provide them with printed images of the front side and explanations of the visual presentations.

More than for other fireworks, we must for 1713 distinguish between the 'castle', i.e. the constructed substrate of a durable character and the concrete representations built upon it, and, on the other hand, the fireworks performance in the proper sense of the word, by definition short-lived and volatile. Consequently, a clear distinction must also be made between the realms of meaning involved. Yet the theatre and the performance were closely intertwined, and it would be an error to consider the fiery performance as an autonomous spectacle of a lower cultural level for the common people, while the fireworks theatre served as an implement for the learned elite. In fact, all published representations, engravings and broadsheets of the fireworks display a perfect match between performance and theatre. These engravings were reproduced many times by printers in The Hague, Utrecht and Amsterdam, and even abroad, in numbers we do not know but which must have been important. The popular market for such items went well beyond the social upper crust. The publishers competed in their claims that their own product was the most perfect reproduction of the event, providing the most complete explanation of the fireworks castle and its meanings. Finally, the journal Europische Mercurius reproduced the descriptions of the fireworks in full, making their messages available for those who had not been able to attend the performance and separating the documentary and educational function of the spectacle from the performance itself. ${ }^{21}$ In that way, the message provided became a formal, long-lasting element of the narrative about the Peace negotiations and the Treaty of Utrecht.

Yet the engravings clearly represent the double impact of the fireworks, learned and popular together. They connect the instantaneous event with the durable setting and make them understandable in their mutual relation. The scenery shows how the short-lived rockets and other implements are released from the top of the fixed components of the theatre. Instead of 
remaining simple construction elements, the presence of these components is emphasized by the fire, and the spectacle inspires a search for their meaning, the more so as that meaning is symbolically or metaphorically included in the emblematic figures represented on the components. Therefore, performance and visual representation reinforce each other in the act-public and at the same time very personal- by which the fireworks are emotionally experienced and mentally assimilated. The rich, intricate, but basically stable and rather heavy structure of the theatre contrasts so strikingly with the airy and fiery performance represented by the visual, auditory and olfactory experience of the exploding fire, that it produces a strong mental impulsion to look for a collective meaning that unites the spectator and the community in a single act of appropriation of the event. On the other hand, the interpretation of the meaning of the emblematic representations, including the structure of the theatre itself, is intensified by the memory of the fiery explosions, just as it is guided by the visual repertories from which they are borrowed and to which they refer in the memory of the spectators and interpreters.

These visual repertories pertained to the visual domains that were common knowledge for the contemporaries, at least for those who had gone to school, as was the case of the majority of the Dutch population as early as the late sixteenth century. We may retrieve them from the formal or visual conventions of the world of art, of printed publications, and of any other form of decoration, even the most basic ones in print work or house decoration. The selection that had to be made in the extremely rich domain of the available forms of figuration proved to be mostly political, sometimes linked with social and moral considerations. The documentation produced before, during and after the fireworks shows that the inventors or designers of the fireworks developed a visual programme that corresponded closely to the political message which the organizing authorities wanted to be inculcated by the combination of performance and representation. But for visualizing concepts and ideas, they needed a translation into a visual repertory that could be recognized, either because it had long formed part of society's memory and charged with precise, recognizable meanings for everybody or because it had been learned for use in precise situations or conditions. In theory it would have been possible, and perhaps more effective in the short run, to represent political ideas in the form of a strictly contemporary performance, for example by marking with precision the adversaries, performing a battle on the stage or at least showing its results, or representing a negotiation in action, as it would be done in the 2013 fireworks theatre in Utrecht.

However, there were at least three reasons for not clinging too closely to the political world of those years but instead adopting a more distant language of 
representation. Firstly, the peace had been achieved with difficulty and its issue was still pending for a number of belligerents; therefore caution was needed. Secondly, ever since the Middle Ages the representation of political realities had been moulded in symbolic imagery and more precisely in emblematic heraldry. Thirdly, the political language was fundamentally designed and controlled by the social elite, which, in spite of the predominance of the early modern court culture and the civilité register in its social life, had been educated in the classical culture of the Latin schools and universities. The symbolic language of Greco-Roman Antiquity or the register of the biblical references constituted therefore its main reference frame. Peace, for instance, was always represented by an emblematic figure referring to either the Greco-Roman pantheon with its innumerable deities or to the Judeo-Christian world with its biblical figures, angels or early Christian saints at the centre of the stage.

\section{Conclusion}

The rich emblems and metaphors would need a more thorough analysis of this complicated imagery. The apparent global language of the imagery is treacherous because it hides diverse political, social and cultural meanings and changing cultures of memory. Allow me just a triple conclusion. First, seen from the point of view of public festivities, the Peace of Utrecht appears indeed as the zenith of a long evolution and as the summit of the art of firework-making, in its pyrotechnical aspects as well as regards political representation. Given the lavish execution of the fireworks castles and the extremely broad diffusion of the visual publications and their textual explanations, we may conclude that the authorities of the time were quite aware of the exceptional weight of what happened at that moment and purposely tried to make it benefit their cause.

Second, with respect to that public cause, the present-day observer cannot refrain from a certain disappointment. With the exception of a general sense of relief because of the peace, the sumptuous, even magnificent emblematic decoration programmes remain totally inward-turned, inside the boundaries of the Dutch Republic and the structures of the state. They support a patriotic mentality. Again with the exception of some general references to commerce, they do not refer at all to any form of alliance, any expansion worldwide or any responsibility of the Dutch in the political theatre of Europe. Paradoxically, it is the political structure of the Dutch community itself that is celebrated, whereas this structure was of virtually no importance for the peace negotiations. 1713 displays a nationalizing celebration, a return to patriotism organized by the highest authorities of the provinces and the state itself, not the 
festive and trustful proclamation of the international creed one would expect from them on the threshold of the cosmopolitan Enlightenment. Was this magnificent but disappointing turning inward a political conjuration of inner dangers, of the fear of disintegration of the Dutch commonwealth? At any rate, the authorities must have realised that the leading European role of the Dutch was finished and must have consequently adapted the educational message of the fireworks to the changing times.

Thirdly, and more generally, I hope to have shown in this short analysis that early modern fireworks represent much more than the bit of idle entertainment they may have provided at first sight. The fireworks formula was used by the political authorities with a triple aim: a celebratory function, a recreational function, and, much more than nowadays, an educational function for their political cause. This third function justified the considerable expense of the fireworks, both as a volatile performance and as a more durable theatre for political messages. In the early modern period, the fireworks on the occasion of the Peace of Utrecht were probably the most perfect and most balanced expression of this double goal. 